\title{
MENDETEKSI ORISINALITAS CITRA DIGITAL DENGAN MENERAPKAN METODE ADLER-32
}

\author{
Jelita Lahagu \\ Program Studi Teknik Informatika STMIK BUDI DARMA, Medan, Indonesia \\ Email : jelitakisaran@gmail.com
}

\begin{abstract}
Abstrak
Perkembangan citra digital sekarang sangat pesat, dimana pengolahan data gambar, dokumen pada citra digital tersebut membuat citra mudah dibuat atau di manipulasi dengan mudah, bahkan tanpa meninggalkan petunjuk jejak visual oleh pengguna untuk keperluan dalam memenipulasi suatu citra. Kemudahan dalam membuat dan merubah suatu citra dapat merusak kredibilitas orisinalitas/keaslian citra dalam berbagai aspek. Citra merupakan kombinasi antara titik, garis, bidang, dan warna untuk menciptakan suatu imitasi dari suatu objek. Berdasarkan hal tersebut membuat perubahan pixel citra asli sehingga tidak menunjukkan citra asli atau citra tersebut sudah di manipulasi. Dengan demikian maka pendeteksian pada citra dapat diketahui keaslian suatu citra dengan menggunakan Algoritma Adler-32. Perubahan kecil dari piksel tidak membuat konten gambar terdeteksi oleh mata manusia. Hal ini dijelaskan dalam pixel seperti lebar panjang pada gambar. menjadi dasar penelitian ini untuk mendeteksi orisinalitas atau keaslian suatu citra digital.
\end{abstract}

Kata Kunci :Citra, Orisinalitas, Manipulasi, Adler-32.

\section{Abstract}

The development of digital images is now very rapid, where the processing of image data, documents on digital images make images easily created or manipulated easily, even without leaving a visual imprint for users to manipulate an image. The ease in making and changing an image can damage the credibility of the originality / authenticity of the image in various aspects.Image is a combination of points, lines, shapes and colors to create an imitation of an object. Based on this, the pixel changes the original image so that it does not indicate the original image or the image has been manipulated. Thus the detection of the image can be known the authenticity of an image using the Adler-32 Algorithm. Small changes of pixels do not make the image content detected by the human eye. This is explained in pixels like the long width in the image. The basis of this research is to detect the originality or authenticity of a digital image.

Keywords : Image, Originality, Manipulation, Adler-32

\section{PENDAHULUAN}

Perkembangan citra digital sekarang sangat pesat, di mana pengolahan data gambar, dokumen pada citra digital tersebut membuat citra mudah dibuat atau di manipulasi dengan mudah, bahkan tanpa meninggalkan petunjuk jejak visual oleh pengguna untuk keperluan dalam memanipulasi suatu citra. Kemudahan dalam membuat dan merubah suatu citra dapat merusak kredibilitas orisinalitas/keaslian citra dalam berbagai aspek.

Citra merupakan kombinasi antara titik, garis, bidang, dan warna untuk menciptakan suatu imitasi dari suatu objek., banyak peralatan elektronik yang sering digunakan misalnya scanner, kamera digital, dan fingerprint reader (pembaca sidik jari) yang menghasilkan citra digital. Perangkat lunak untuk mengolah citra digital juga sangat populer, pengguna mengolah gambar untuk berbagai keperluan lain sebagai contoh menggunakan aplikasi photo scape, adobe Photoshop dan GIMP (GNU image Manipulation Program) yang menyajikan berbagai fitur dalam memanipulasi citra digital.

Mendeteksi orisinalitas citra digital merupakan cara untuk mengetahui keaslian suatu gambar. Dengan demikian metode ini berperan penting di berbagai aspek. Selain mempermudah penggunanya juga dapat meningkatkan kinerja dalam tugas-tugas yang dikerjakan khususnya dalam pendeteksian orisinalitas citra digital. Metode Adler-32 ini sesungguhnya menggunakan prinsip dasar dalam citra digital seperti pencarian bentuk objek dan perubahan pixel pada gambar.

Hal ini dilakukan dalam pengolahan gambar adalah mengubah gambar warna ke gambar grayscale. Gambar warna terdiri dari tiga lapisan, merah, hijau dan biru, Proses grayscale adalah untuk mencampur lapisan dan menghasilkan warna lapisan tunggal. Ketika ada perhitungan dilakukan dengan menggunakan tiga lapisan, itu akan berubah dengan mengelompokkan lapisan ketiga menjadi grayscale dan hasilnya adalah gambar grayscale, hanya gradasi hitam dan putih. Algoritma Adler-32 diciptakan oleh Mark Adler padan tahun 1995 menemukan fungsi hash Adler-32 dan dimodifikasi checksum fletcher. Panjangnya sama dengan CRC. Ia mengklaim bahwa Adler-32 ini adalah lebih dapat diandalkan dibandingkan fletcher 16 dan sedikit kurang diandalkan dibandingkan fletcher 32. Hal ini diperoleh dengan menghitung dua 16-bit nilai A dan B ke integer 32-bit dengan nilai hexadecimal.[1]

\section{TEORITAS}

\subsection{Pengertian Citra}


Citra adalah suatu representasi (gambaran), visual, kombinasi antara titik, garis, bidang dan warna kemiripan atau imitasi dari suatu objek. atau beberapa objek. Wujud citra bermacam-macam, seperti perekaman data bersifat optic berupa foto, bersifat analog berupa sinyal video seperti gambar pada monitor televisi, atau bersifat digital yang dapat langsung disimpan pada suatu media penyimpanan.[3] Citra merupakan istilah lain untuk gambar sebagai salah satu komponen multimedia yang memegang peranan yang sangat penting sebagai bentuk informasi visual.

Citra mempunyai karakteristik yang tidak dimiliki oleh data teks, yaitu citra kaya dengan informasi.

\subsection{Citra Digital}

Citra digital merupakan sebagai pemrosesan gambar citra dua dimensi dengan menggunakan komputer. Dalam konteks yang lebih luas, pengolahan citra digital juga mencakup pada pemrosesan setiap data dua dimensi. Citra digital adalah barisan bilangan nyata maupun kompleks yang diwakili oleh bit-bit tertentu. Unit terkecil dari data digital adalah bit, yaitu angka biner, 0 atau 1.[4] kumpulan dari data sejumlah 8 bit data adalah sebuah unit data yang disebut byte, dengan nilai dari 0-225.

Dalam hal citra digital, nilai level energi dituliskan dalam satuan byte ini dengan struktur tertentu bisa dicoba oleh software dan disebut citra digital 8 bit. Metode Adler-32 merupakan Algoritma pengamanan data, Mark Adler menemukan fungsi Hash Adler-32, dan dimodifikasi checksum Fletcher. Panjangnya sama dengan CRC. Hal ini menawarkan kecepatan proses validasi Adler-32.

Mark Adler mengklaim bahwa Adler-32 adalah lebih dapat diandalkan dibandingkan Fletcher-16 dan sedikit kurang diandalkan dibandingkan Fletcher-32.[1] Keluaran dari algoritma Adler-32 di dapat dari perhitungan dua bilangan 16-bit A dan B. Bilangan A dan B ini kemudian akan dikonkatenasi menjadi bilangan integer 32 bit.

A adalah jumlah dari semua byte di string ditambah dengan satu, sedangkan B adalah jumlah dari setiap nilai-nilai dari A dari setiap langkah. Pada permulaan metode Adler-32, nilai A diinisialisasi dengan nilai 1, sedangkan B diinisialisasi dengan nilai 0 . Hasil dari perjumlahan kemudian akan di modulo dengan 65221, yang merupakan bilangan prima terbesar yang lebih kecil dari 16 .[2] Fungsi Adler-32 ini dapat di ekspresikan sebagai berikut:

A $\quad=1+\mathrm{D}_{1}+\mathrm{D}_{2}+\ldots+\mathrm{D}_{n}(\bmod 65521)$

B $\quad=\left(1+D_{1}\right)+\left(1+D_{1}+D_{2}\right)+\ldots+\left(1+D_{1}+D_{2}+\ldots+D_{n}\right)(\bmod 65521)$

$=\mathrm{n} \times \mathrm{D}_{1}+(\mathrm{n}-1) \times \mathrm{D}_{2}+(\mathrm{n}-2) \times \mathrm{D}_{3}+\ldots+\mathrm{D}_{n}+\mathrm{n}(\bmod 65521)$

Adler-32 (D) = B x 65536 + A

Analisa dan Pembahasan Proses pendeteksian orisinalitas citra digital di lakukan dengan menggunakan citra scan ijazah asli yang menjadi sample dalam penelitian dan dikonversi ke warna RGB menjadi nilai grayscale dengan menggunakan Matlab.

Dalam metode ini akan menghitung nilai pixel grayscale dengan menerapkan metode adler-32 sehingga menghasilkan nilai hash orisinalitas citra dan citra manipulasi. Pendeteksian orisinalitas citra ini dilakukan dengan tujuan agar dapat mengetahui kelebihan dan kekurangan dalam mendeteksi orisinalitas suatu gambar. Jenis gambar yang di deteksi dengan format JPG (Joint Photographic Group).

Ada pun gambar diagram alur relaksi orisinalitas citra akan tampak pada gambar di bawah ini:

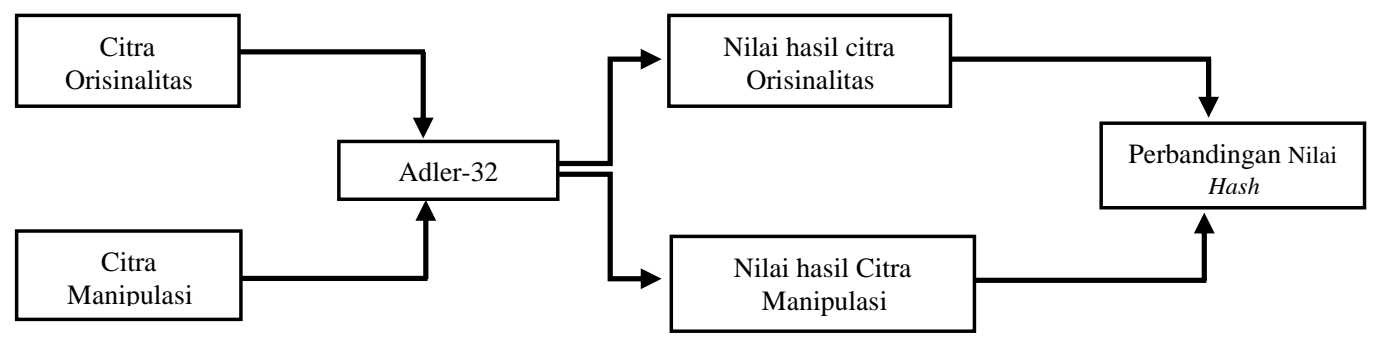

Gambar 1 Diagram relaksi orisinalitas citra

Diagram relaksi orisinalitas citra Penerapan Metode Adler-32 Metode Adler-32 merupakan Algoritma pengaman data. Penelitian ini, berfungsi untuk menghitung intensitas grayscale pada citra yang memiliki setiap lapisan warna.

Hal ini sebagian besar dilakukan dalam pengolahan gambar adalah mengubah gambar warna ke gambar grayscale, gambar warna memiliki tiga lapisan warna intensitas yaitu: red (merah), green (hijau) dan blue (biru) yang dikombinasikan dengan rata-rata warna RGB. Proses grayscale adalah untuk mencampur lapisan dan menghasilkan warna lapisan tunggal. Dalam gambar ini, tidak ada warna, hanya gradasi hitam dan putih.

Dalam penelitian akan membuat proses gambar warna 15 x 15 piksel. Mencoba menganalisis nilai algoritma Adler-32, di bawah ini menunjukkan gambar asli scan ijazah yang menjadi sample penelitian dan dikonversi ke warna RGB menjadi grayscale. 


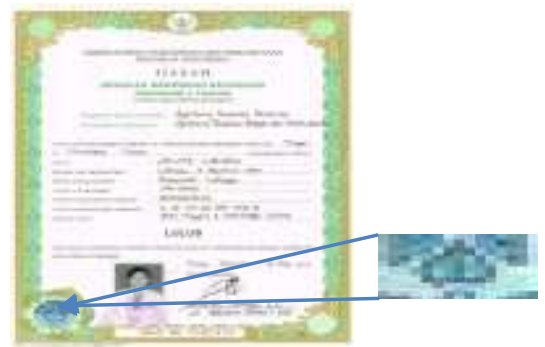

Gambar 2. Citra asli dan citra sampel ukuran 15x15 piksel

Citra asli dan citra sampel ukuran 15x15 piksel Konversikan citra sampel berwarna menjadi citra grayscale dengan menggunakan Matlab R2010a.

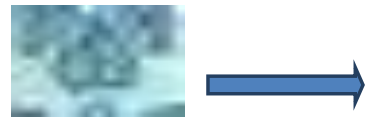

Gambar 3. Konversi Citra sampel Berwarna menjadi Citra Grayscale

Konversi Citra sampel Berwarna menjadi Citra Grayscale Tampilkan nilai piksel grayscale citra sampel yang telah dikonversi.

Tabel 1. Nilai Grayscale Citra Sampel

\begin{tabular}{lllllllllllllll}
\hline 164 & 136 & 120 & 140 & 118 & 140 & 220 & 186 & 189 & 144 & 129 & 159 & 146 & 143 & 227 \\
170 & 145 & 130 & 121 & 150 & 147 & 177 & 120 & 192 & 149 & 149 & 91 & 123 & 147 & 228 \\
181 & 132 & 129 & 153 & 155 & 155 & 156 & 110 & 174 & 144 & 163 & 109 & 130 & 130 & 212 \\
182 & 143 & 147 & 159 & 130 & 208 & 107 & 116 & 112 & 184 & 137 & 171 & 145 & 154 & 223 \\
163 & 152 & 148 & 143 & 163 & 163 & 90 & 139 & 115 & 179 & 143 & 170 & 140 & 143 & 210 \\
166 & 140 & 110 & 179 & 159 & 111 & 133 & 137 & 178 & 123 & 200 & 151 & 108 & 142 & 211 \\
191 & 124 & 165 & 215 & 110 & 144 & 149 & 124 & 164 & 135 & 167 & 210 & 152 & 152 & 217 \\
208 & 200 & 203 & 165 & 115 & 162 & 151 & 119 & 149 & 162 & 123 & 212 & 228 & 245 & 235 \\
219 & 202 & 203 & 161 & 137 & 187 & 153 & 121 & 170 & 157 & 119 & 214 & 231 & 236 & 241 \\
206 & 218 & 214 & 192 & 115 & 181 & 151 & 139 & 192 & 153 & 125 & 216 & 214 & 218 & 224 \\
199 & 213 & 218 & 220 & 108 & 137 & 120 & 106 & 121 & 105 & 158 & 218 & 225 & 210 & 237 \\
212 & 211 & 205 & 201 & 208 & 137 & 194 & 197 & 179 & 181 & 212 & 219 & 205 & 223 & 229 \\
213 & 214 & 229 & 217 & 223 & 213 & 221 & 167 & 221 & 217 & 207 & 213 & 224 & 223 & 240 \\
167 & 205 & 189 & 217 & 226 & 213 & 137 & 175 & 137 & 209 & 224 & 226 & 194 & 175 & 133 \\
128 & 113 & 130 & 185 & 217 & 177 & 140 & 192 & 130 & 205 & 223 & 172 & 139 & 134 & 127 \\
\hline
\end{tabular}

Tabel di atas menunjukkan perhitungan grayscale. Tabel ini akan menjadi data lebih lanjut yang digunakan perhitungan untuk menemukan nilai Adler-32. Nilai ini diperoleh dengan menerapkan rumus untuk nilai piksel tersebut.

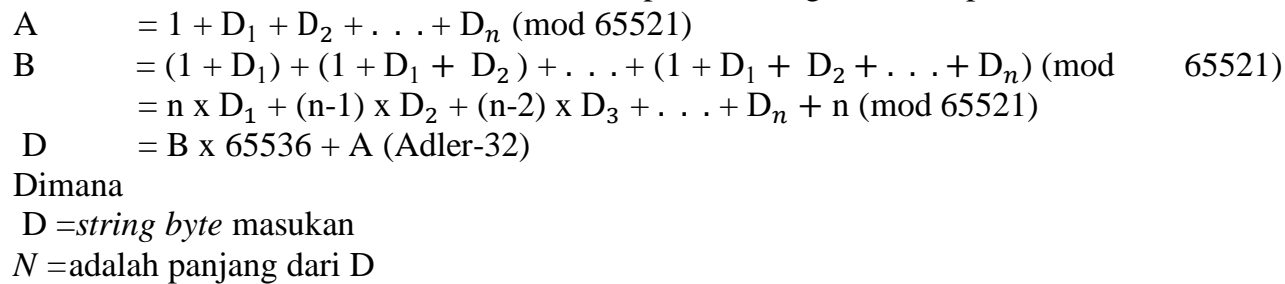

Proses perhitungan nilai piksel Grayscale dengan menggunakan algoritma Adler-32 adalah sebagai berikut :

Tabel 2.

Tabel 2. Perhitungan Adler-32

\begin{tabular}{lllllllll}
\hline No & A & B & No & A & B & No & A & B \\
\hline 1 & 1 & 0 & 51 & 7,595 & 194,633 & 101 & 15,182 & 767,859 \\
2 & 165 & 165 & 52 & 7,803 & 202,436 & 102 & 15,349 & 783,208 \\
3 & 301 & 466 & 53 & 7,910 & 210,346 & 103 & 15,559 & 798,767 \\
4 & 421 & 887 & 54 & 8,026 & 218,372 & 104 & 15,711 & 814,478 \\
5 & 561 & 1,448 & 55 & 8,138 & 226,510 & 105 & 15,863 & 830,341
\end{tabular}




\begin{tabular}{|c|c|c|c|c|c|c|c|c|}
\hline & & & 56 & & & 106 & & \\
\hline 7 & 19 & 946 & & & & 107 & & \\
\hline & 039 & & & & & 108 & & \\
\hline & 225 & 210 & & & & 109 & & \\
\hline & 414 & & & & & 110 & & \\
\hline & 558 & & & & & 111 & & \\
\hline & 687 & 869 & & & & 112 & & 84 \\
\hline & & & & & & 113 & & \\
\hline & 992 & 7 & & & & 114 & & \\
\hline & 135 & & & & & 15 & & \\
\hline & 362 & & & & & 116 & & \\
\hline & 532 & & & & & 117 & & \\
\hline & 677 & & & & & 118 & & \\
\hline & 807 & & & & & 19 & & \\
\hline & 928 & & & & & 120 & & \\
\hline & & & & & & 121 & & \\
\hline & 5 & & & & & 122 & & \\
\hline & 402 & & & & & 123 & & \\
\hline & 522 & 75 & 7 & & & 124 & & \\
\hline & 14 & & & & & 125 & & \\
\hline & & & & & & 126 & & \\
\hline & & & & & & 127 & & \\
\hline & & & & & & 128 & & \\
\hline & & & & & & & & \\
\hline & & & & & & 30 & & \\
\hline & 601 & & & & & 131 & & \\
\hline & 782 & & & & & 132 & & \\
\hline & 914 & & & & & 3 & & \\
\hline & & & & & & & & \\
\hline & & & & & & 135 & & \\
\hline & & & & & & 36 & & \\
\hline & & & & & & & & \\
\hline & & & & & & 8 & & \\
\hline & 772 & & & & & 39 & & \\
\hline & & & & & & 40 & & \\
\hline & 090 & & & & & & & \\
\hline & 253 & & & & & & & \\
\hline 43 & & & 9 & & & 143 & & \\
\hline 44 & & & & & & 144 & & \\
\hline & & & & & & & & \\
\hline & & & & & & & & \\
\hline & & & & & & & & \\
\hline & & & & & & & & \\
\hline & & & & & & & & \\
\hline 50 & 7,465 & 187,038 & 100 & 15,047 & 752,677 & 150 & 24,042 & $1,731,1$ \\
\hline
\end{tabular}

\begin{tabular}{lllllllll}
\hline No & A & B & No & A & B & No & A & B \\
\hline 151 & 24,266 & $1,755,440$ & 176 & 28,786 & $2,419,343$ & 201 & 34,120 & $3,208,845$ \\
152 & 24,465 & $1,779,905$ & 177 & 28,998 & $2,448,341$ & 202 & 34,333 & $3,243,178$ \\
153 & 24,678 & $1,804,583$ & 178 & 29,217 & $2,477,558$ & 203 & 34,470 & $3,277,648$ \\
154 & 24,896 & $1,829,479$ & 179 & 29,422 & $2,506,980$ & 204 & 34,645 & $3,312,293$ \\
155 & 25,116 & $1,854,595$ & 180 & 29,645 & $2,536,625$ & 205 & 34,782 & $3,347,075$ \\
156 & 25,224 & $1,879,819$ & 181 & 29,874 & $2,566,499$ & 206 & 34,991 & $3,382,066$ \\
157 & 25,361 & $1,905,180$ & 182 & 30,087 & $2,596,586$ & 207 & 35,215 & $3,417,281$ \\
158 & 25,481 & $1,930,661$ & 183 & 30,301 & $2,626,887$ & 208 & 35,441 & $3,452,722$
\end{tabular}




\begin{tabular}{lllllllll}
159 & 25,587 & $1,956,248$ & 184 & 30,530 & $2,657,417$ & 209 & 35,635 & $3,488,357$ \\
160 & 25,708 & $1,981,956$ & 185 & 30,747 & $2,688,164$ & 210 & 35,810 & $3,524,167$ \\
161 & 25,813 & $2,007,769$ & 186 & 30,970 & $2,719,134$ & 211 & 35,943 & $3,560,110$ \\
162 & 25,971 & $2,033,740$ & 187 & 31,183 & $2,750,317$ & 212 & 36,071 & $3,596,181$ \\
163 & 26,189 & $2,059,929$ & 188 & 31,404 & $2,781,721$ & 213 & 36,184 & $3,632,365$ \\
164 & 26,414 & $2,086,343$ & 189 & 31,571 & $2,813,292$ & 214 & 36,314 & $3,668,679$ \\
165 & 26,624 & $2,112,967$ & 190 & 31,792 & $2,845,084$ & 215 & 36,499 & $3,705,178$ \\
166 & 26,861 & $2,139,828$ & 191 & 32,009 & $2,877,093$ & 216 & 36,716 & $3,741,894$ \\
167 & 27,073 & $2,166,901$ & 192 & 32,216 & $2,909,309$ & 217 & 36,893 & $3,778,787$ \\
168 & 27,284 & $2,194,185$ & 193 & 32,429 & $2,941,738$ & 218 & 37,033 & $3,815,820$ \\
169 & 27,489 & $2,221,674$ & 194 & 32,653 & $2,974,391$ & 219 & 37,225 & $3,853,045$ \\
170 & 27,690 & $2,249,364$ & 195 & 32,876 & $3,007,267$ & 220 & 37,355 & $3,890,400$ \\
171 & 27,898 & $2,277,262$ & 196 & 33,116 & $3,040,383$ & 221 & 37,560 & $3,927,960$ \\
172 & 28,035 & $2,305,297$ & 197 & 33,283 & $3,073,666$ & 222 & 37,783 & $3,965,743$ \\
173 & 28,229 & $2,333,526$ & 198 & 33,488 & $3,107,154$ & 223 & 37,955 & $4,003,698$ \\
174 & 28,426 & $2,361,952$ & 199 & 33,677 & $3,140,831$ & 224 & 38,094 & $4,041,792$ \\
175 & 28,605 & $2,390,557$ & 200 & 33,894 & $3,174,725$ & 225 & 38,228 & $4,080,020$ \\
& & & & & & 226 & 38,355 & $4,118,375$ \\
\hline
\end{tabular}

Ada 225 piksel $(15 \times 15)+1$ perhitungan. No $1, A=1$ dan $B=0$ Nilai A terakhir menunjukkan 38,355 dan nilai terakhir $\mathrm{B}$ menunjukkan 4,118,375 perhitungan ini tidak berakhir.

$$
\begin{aligned}
\mathrm{A} & =\mathrm{A} \% \text { MOD_ADLER } \\
& =\mathrm{A} \% 65521 \\
& =38355 \% 65521 \\
& =\mathbf{3 8 3 5 5} \\
\mathrm{B} & =\mathrm{B} \% \text { MOD_ADLER } \\
& =\mathrm{B} \% 65221 \\
& =4118375 \% 65521 \\
\mathrm{AD} & =\mathbf{5 6 0 7 3} \\
& =\mathrm{B} .65536+\mathrm{A} \\
& =56073.65536+38355 \\
& =\mathbf{3 6 7 4 8 3 8 4 8 3} \text { (decimal) }
\end{aligned}
$$

Adler-32 berjalan dalam heksadesimal . nilai dalam hexadecimal adalah DB0995D3. Nilai ini adalah kombinasi dari dua nilai 16-bit.

Sehingga nilai hasil citra orisinalitas terdeteksi menunjukkan gambar asli. Bagaimana jika konten telah dimodifikasi atau ada benda terdeteksi kecil telah dimasukkan ke dalam gambar tersebut. Ini adalah untuk membuktikan fungsi hash. Hal ini adalah tidak dapat terdeteksi oleh mata telanjang. Orisinalitas dapat dideteksi hanya dengan menggunakan program komputer.

Tabel di bawah menunjukkan nilai grayscale yang telah dimodifikasi dari nilai grayscale sebelumnya.

Tabel 3. Nilai Grayscale proses modifikasi

\begin{tabular}{rrrrrrrrrrrrrrr}
\hline 157 & 128 & 113 & 133 & 112 & 132 & 217 & 182 & 183 & 138 & 121 & 153 & 140 & 137 & 224 \\
163 & 138 & 123 & 115 & 144 & 139 & 172 & 113 & 187 & 142 & 143 & 84 & 117 & 139 & 226 \\
176 & 124 & 121 & 146 & 148 & 148 & 150 & 101 & 169 & 138 & 157 & 102 & 121 & 123 & 208 \\
177 & 136 & 141 & 152 & 123 & 203 & 100 & 109 & 103 & 178 & 130 & 166 & 140 & 149 & 220 \\
158 & 146 & 142 & 137 & 157 & 157 & 82 & 131 & 106 & 174 & 137 & 165 & 134 & 136 & 207 \\
160 & 133 & 103 & 174 & 153 & 104 & 126 & 129 & 173 & 116 & 195 & 145 & 100 & 136 & 209 \\
185 & 118 & 159 & 211 & 103 & 136 & 143 & 116 & 158 & 128 & 163 & 205 & 146 & 145 & 214 \\
204 & 194 & 198 & 159 & 107 & 156 & 144 & 112 & 143 & 155 & 117 & 210 & 224 & 245 & 232 \\
218 & 197 & 198 & 154 & 130 & 181 & 146 & 115 & 163 & 152 & 112 & 211 & 228 & 235 & 242 \\
203 & 214 & 213 & 186 & 106 & 175 & 145 & 133 & 188 & 148 & 118 & 212 & 211 & 216 & 221 \\
193 & 212 & 212 & 217 & 100 & 130 & 112 & 97 & 114 & 97 & 152 & 215 & 223 & 208 & 236 \\
209 & 208 & 202 & 196 & 205 & 130 & 189 & 191 & 173 & 176 & 209 & 216 & 200 & 219 & 227 \\
210 & 211 & 228 & 215 & 221 & 209 & 219 & 162 & 219 & 214 & 202 & 209 & 223 & 221 & 239
\end{tabular}




\begin{tabular}{lllllllllllllll}
161 & 202 & 183 & 215 & 222 & 210 & 131 & 171 & 131 & 204 & 223 & 223 & 191 & 169 & 126 \\
\hline
\end{tabular}

Perhitungan nilai grayscale yang telah dimodifikasi menggunakan Adler-32

Tabel 4. Proses Perhitunganmodifikasi

\begin{tabular}{|c|c|c|c|c|c|c|c|c|}
\hline No & $\mathbf{A}$ & B & No & $\mathbf{A}$ & B & No & $\mathbf{A}$ & B \\
\hline 1 & 1 & 0 & 39 & 5,591 & 109,074 & 77 & 11,189 & 430,092 \\
\hline 2 & 157 & 158 & 40 & 5,748 & 114,822 & 78 & 11,322 & 441,414 \\
\hline 3 & 285 & 443 & 41 & 5,850 & 120,672 & 79 & 11,425 & 452,839 \\
\hline 4 & 398 & 841 & 42 & 5,971 & 126,643 & 80 & & 464,438 \\
\hline 5 & 531 & 1,372 & 43 & 6,094 & 132,737 & 81 & & 476,190 \\
\hline 6 & 643 & 2,015 & 44 & 6,302 & 139,039 & 82 & & 488,046 \\
\hline 7 & 775 & 2,790 & 45 & 6,425 & 145,464 & 83 & 11,982 & 500,028 \\
\hline 8 & 992 & 3,782 & 46 & 6,633 & 152,097 & 84 & 12,111 & 512,139 \\
\hline 9 & 1,174 & 4,956 & 47 & 6,810 & 158,907 & 85 & 12,284 & 524,423 \\
\hline 10 & 1,357 & 6,313 & 48 & 6,946 & 165,853 & 86 & 12,400 & 536,823 \\
\hline 11 & 1,495 & 7,808 & 49 & 7,087 & 172,940 & 87 & 12,595 & 549,418 \\
\hline 12 & 1,616 & 9,424 & 50 & 7,239 & 180,179 & 88 & 12,740 & 562,158 \\
\hline 13 & 1,769 & 11,193 & 51 & 7,362 & 187,541 & 89 & 12,840 & 574,998 \\
\hline 14 & 1,909 & 13,102 & 52 & 7,565 & 195,106 & 90 & 12,976 & 587,974 \\
\hline 15 & 2,046 & 15,148 & 53 & 7,665 & 202,771 & 91 & 13,185 & 601,159 \\
\hline 16 & 2,270 & 17,418 & 54 & 7,774 & 210,545 & 92 & 13,370 & 614,529 \\
\hline 17 & 2,433 & 19,851 & 55 & 7,877 & 218,422 & 93 & 13,488 & 628,017 \\
\hline 18 & 2,571 & 22,422 & 56 & 8,055 & & 94 & 13,647 & 641,664 \\
\hline 19 & 2,694 & 25,11 & 57 & & & 95 & & 655,522 \\
\hline 20 & 2,809 & 27,9 & 58 & 51 & & 96 & & 669,483 \\
\hline 21 & 2,953 & 30,878 & 59 & 8,491 & 504 & 97 & 14,097 & 683,580 \\
\hline 22 & 3,092 & 33,970 & 60 & 8,640 & 260,144 & 98 & 14,240 & 697,820 \\
\hline 23 & 3,264 & 37,234 & 61 & 8,860 & 269,004 & 99 & 14,356 & 712,176 \\
\hline 24 & 3,377 & 40,611 & 62 & 9,018 & 278,022 & 100 & 14,514 & 726,690 \\
\hline 25 & 3,564 & 44,175 & 63 & 9,164 & 287,186 & 101 & 14,642 & 741,332 \\
\hline 26 & 3,706 & & 64 & 9,306 & & 102 & & 6,137 \\
\hline 27 & 3,849 & & 65 & 9,443 & & 103 & & 771 \\
\hline 28 & & & 66 & & & 10 & & 303 \\
\hline 29 & 4,050 & 59,7 & 67 & 9,757 & 92 & 105 & & 801,604 \\
\hline 30 & 4,189 & 63,902 & 68 & 9,839 & 335,131 & 106 & 15,515 & 817,119 \\
\hline 31 & 4,415 & 68,317 & 69 & 9,970 & 345,101 & 107 & 15,719 & 832,838 \\
\hline 32 & 4,591 & 72,908 & 70 & 10,076 & 355,177 & 108 & 15,913 & 848,751 \\
\hline 33 & 4,737 & 77,645 & 71 & 10,250 & 365,427 & 109 & 16,111 & 864,862 \\
\hline 34 & 4,885 & 82,530 & 72 & 10,387 & 375,814 & 110 & 16,270 & 881,132 \\
\hline 35 & 5,033 & 87,563 & 73 & 10,552 & 386,366 & 111 & 16,377 & 897,509 \\
\hline 36 & 5,183 & 92,7 & 74 & 10,6 & 397,0 & 11 & 16 & 914,042 \\
\hline 37 & 5,284 & 98,030 & 75 & 10,822 & 407,8 & 113 & 16,677 & 930,719 \\
\hline 38 & 5,453 & 103,483 & 76 & 11,029 & 418,903 & 114 & 16,789 & 947,508 \\
\hline
\end{tabular}

\begin{tabular}{ccccccccc}
\hline No & A & B & No & A & B & No & A & B \\
\hline 115 & 16,932 & 964,440 & 153 & 23,891 & $1,743,063$ & 191 & 31,062 & $2,782,074$ \\
116 & 17,087 & 981,527 & 154 & 24,103 & $1,767,166$ & 192 & 31,264 & $2,813,338$ \\
117 & 17,204 & 998,731 & 155 & 24,320 & $1,791,486$ & 193 & 31,473 & $2,844,811$ \\
118 & 17,414 & $1,016,145$ & 156 & 24,420 & $1,815,906$ & 194 & 31,696 & $2,876,507$ \\
119 & 17,638 & $1,0337,83$ & 157 & 24,550 & $1,840,456$ & 195 & 31,917 & $2,908,424$ \\
120 & 17,883 & $1,051,666$ & 158 & 24,662 & $1,865,118$ & 196 & 32,156 & $2,940,580$ \\
121 & 18,115 & $1,069,781$ & 159 & 24,759 & $1,889,877$ & 197 & 32,317 & $2,972,897$ \\
122 & 18,333 & $1,088,114$ & 160 & 24,873 & $1,914,750$ & 198 & 32,519 & $3,005,416$ \\
123 & 18,530 & $1,106,644$ & 161 & 24,970 & $1,939,720$ & 199 & 32,702 & $3,038,118$
\end{tabular}




\begin{tabular}{lllllllll}
124 & 18,728 & $1,125,372$ & 162 & 25,122 & $1,964,842$ & 200 & 32,917 & $3,071,035$ \\
125 & 18,882 & $1,144,254$ & 163 & 25,337 & $1,990,179$ & 201 & 33,139 & $3,104,174$ \\
126 & 19,012 & $1,163,266$ & 164 & 25,560 & $2,015,739$ & 202 & 33,349 & $3,137,523$ \\
127 & 19,193 & $1,182,459$ & 165 & 25,768 & $2,041,507$ & 203 & 33,480 & $3,171,003$ \\
128 & 19,339 & $1,201,798$ & 166 & 26,004 & $2,067,511$ & 204 & 33,651 & $3,204,654$ \\
129 & 19,454 & $1,221,252$ & 167 & 26,213 & $2,093,724$ & 205 & 33,782 & $3,238,436$ \\
130 & 19,617 & $1,240,869$ & 168 & 26,421 & $2,120,145$ & 206 & 33,986 & $3,272,422$ \\
131 & 19,769 & $1,260,638$ & 169 & 26,623 & $2,1467,68$ & 207 & 34,209 & $3,306,631$ \\
132 & 19,881 & $1,280,519$ & 170 & 26,819 & $2,173,587$ & 208 & 34,432 & $3,341,063$ \\
133 & 20,092 & $1,300,611$ & 171 & 27,024 & $2,200,611$ & 209 & 34,623 & $3,375,686$ \\
134 & 20,320 & $1,320,931$ & 172 & 27,154 & $2,227,765$ & 210 & 34,792 & $3,410,478$ \\
135 & 20,555 & $1,341,486$ & 173 & 27,343 & $2,255,108$ & 211 & 34,918 & $3,445,396$ \\
136 & 20,797 & $1,362,283$ & 174 & 27,534 & $2,282,642$ & 212 & 35,038 & $3,480,434$ \\
137 & 21,000 & $1,383,283$ & 175 & 27,707 & $2,310,349$ & 213 & 35,143 & $3,515,577$ \\
138 & 21,214 & $1,404,497$ & 176 & 27,883 & $2,338,232$ & 214 & 35,266 & $3,550,843$ \\
139 & 21,427 & $1,425,924$ & 177 & 28,092 & $2,366,324$ & 215 & 35,445 & $3,586,288$ \\
140 & 21,613 & $1,447,537$ & 178 & 28,308 & $2,394,632$ & 216 & 35,660 & $3,621,948$ \\
141 & 21,719 & $1,469,256$ & 179 & 28,508 & $2,423,140$ & 217 & 35,833 & $3,657,781$ \\
142 & 21,894 & $1,491,150$ & 180 & 28,727 & $2,451,867$ & 218 & 35,965 & $3,693,746$ \\
143 & 22,039 & $1,513,189$ & 181 & 28,954 & $2,480,821$ & 219 & 36,152 & $3,729,898$ \\
144 & 22,172 & $1,535,361$ & 182 & 29,164 & $2,509,985$ & 220 & 36,274 & $3,766,172$ \\
145 & 22,360 & $1,557,721$ & 183 & 29,375 & $2,539,360$ & 221 & 36,476 & $3,802,648$ \\
146 & 22,508 & $1,580,229$ & 184 & 29,603 & $2,568,963$ & 222 & 36,695 & $3,839,343$ \\
147 & 22,626 & $1,602,855$ & 185 & 29,818 & $2,598,781$ & 223 & 36,862 & $3,876,205$ \\
148 & 22,838 & $1,625,693$ & 186 & 30,039 & $2,628,820$ & 224 & 36,994 & $3,913,199$ \\
149 & 23,049 & $1,648,742$ & 187 & 30,248 & $2,659,068$ & 225 & 37,121 & $3,950,320$ \\
150 & 23,265 & $1,672,007$ & 188 & 30,467 & $2,689,535$ & & & \\
151 & 23,486 & $1,695,493$ & 189 & 30,629 & $2,7201,64$ & & & \\
152 & 23,679 & $1,719,172$ & 190 & 30,848 & $2,751,012$ & 226 & $\mathbf{3 7 , 2 4 2}$ & $\mathbf{3 , 9 8 7 , 5 6 2}$ \\
\hline
\end{tabular}

Tabel 4. menggambarkan proses perhitungan modifikasi, sebuah nilai modifikasi A menunjukkan 37,242dan modifikasi nilai B 3,987,562. Selain itu nilai-nilai ini sama sekali berbeda dari nilai sebelumnya.

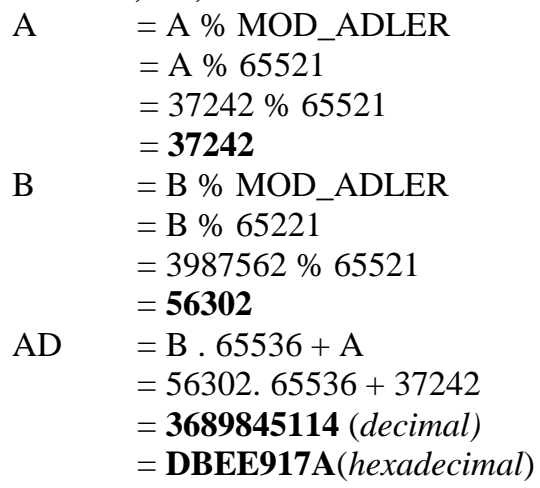

Jika dibandingkan dengan nilai hasil sebelumnya (DB0995D3) meskipun mengubah hanya 1 bit, nilai hash sama sekali berbeda. Metode Adler-32 ini digunakan untuk menguji tingkat orisinalitas gambar. Jika kita memodifikasi salah satu nilai dari RGB atau nilai grayscale akan mempengaruhi untuk sisanya.

Tabel 5 .Perbedaan nilai Hash Citra orisinalitas dan manipulasi

\begin{tabular}{ccc}
\hline \multicolumn{1}{c}{ Citra } & Nilai Hash \\
\hline Citra Orisinalitas & DB3B95D5 \\
Citra Manipulasi & DBEE917A \\
\hline
\end{tabular}


Implementasi Implementasi merupakan suatu proses penerapan cara kerja metode Adler-32 kepada sebuah software dan dijalankan untuk sistem yang telah di rancang berdasarkan hasil analisa dan juga perancangan yang telah dibuat sebelumnya ke dalam suatu bahasa pemograman.

\subsection{Proses Hasil Pendeteksian Citra}

Tampilan menu berikutnya adalah tampilan menu proses hasil pendeteksian citra orisinalitas dan citra manipulasi ditemukan. Menu ini merupakan menu yang berguna untuk membedakan nilai hash citra digital.

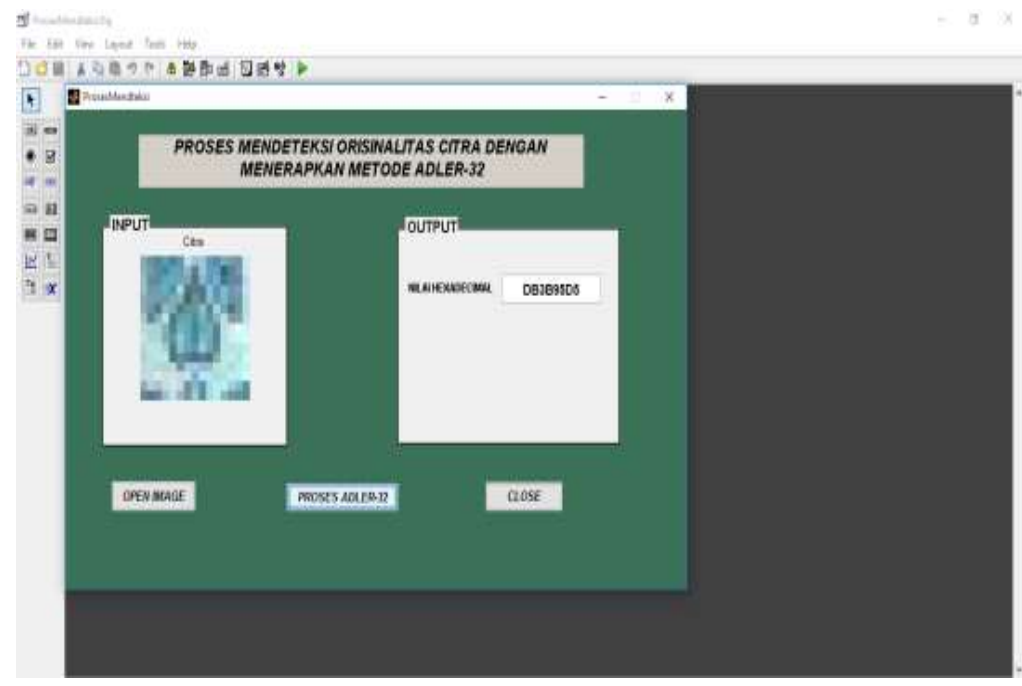

Gambar 5. Menu Proses Hasil Pendeteksian ditemukan.

Pengujian Pengujian merupakan hal terpenting yang bertujuan untuk menemukan hasil yang dideteksi dan mengetahui kinerja dari Metode yang di gunakan untuk mendeteksi orisinalitas citra digital yaitu menggunakan Algoritma Adler-32.

Jika nilai hash yang dihasilkan berbeda, maka metode Adler-32 berhasil mendeteksi perubahan yang terjadi pada citra tersebut. Berikut ini tabel pengujian metode Adler-32.

Tabel 6. Pengujian

\begin{tabular}{|c|c|c|c|c|c|c|}
\hline No & Parameter & $\begin{array}{l}\text { Citra } \\
\text { Asli }\end{array}$ & Nilai Hash & $\begin{array}{l}\text { Citra } \\
\text { Modifikasi }\end{array}$ & Nilai Hash & Keterangan \\
\hline 1 & 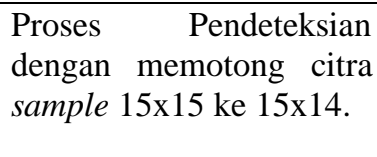 & & DB3B95D5 & & F1373COD & $\begin{array}{l}\text { Dari perbandingan nilai hash dan } \\
\text { nilai hashasli dan yang sudah di } \\
\text { potong, hasilnya berbeda, maka file } \\
\text { gambar dapat terdeteksi. }\end{array}$ \\
\hline
\end{tabular}

2 Proses pendeteksian dengan melakukan save as citra dengan ekstensi berbeda.

3 Proses pendeteksian dengan merotasi citra.

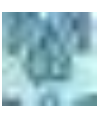

DB3B95D5
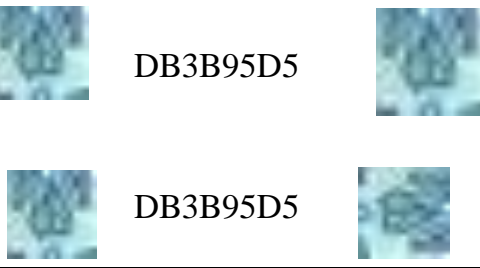

DB3B95D5

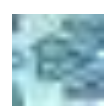

A596C3E2

Dari perbandingan nilai hashsave as citra dengan ekstensi berbeda, maka file gambar dapat terdeteksi.

Dari hasil perbandingan nilai hash B2937B52 rotasi citra, maka file gambar dapat terdeteksi.

\section{Kesimpulan}

Dari hasil eksperimen yang penulis lakukan terhadap penelitian ini, penulis dapat menarik beberapa kesimpulan yang terkait dengan proses penelitian maupun dengan isi dari penelitian itu sendiri. Proses mendeteksi orisinalitas citra dilakukan dengan menggunakan metode Adler-32 dan telah berhasil melakukan proses mendeteksi orisinalitas citra yang berformat Jpg dan berjalan sesuai dengan teknik mendeteksi keasliannya. Analisa metode Algoritma Adler-32 telah berhasil membedakan citra asli dengan citra yang dimodifikasi yaitu dengan membandingkan nilai hash yang dihasilkan 
dari proses perhitungan Algoritma Adler-32. Mendeteksi Orisinalitas dengan metode Algoritma Adler-32 menggunakan Matlab dapat dilakukan dengan membandingkan nilai hash antara citra asli dengan citra yang dimodifikasi. Apabila nilai hash berbeda dari nilai hash citra asli maka diperoleh keputusan bahwa citra tersebut sudah dimodifikasi.

\section{REFERENCES}

[1] Andyash Putera Utama Siahaan “Jurnal A Three-Layer Visual Fungsi Hash Menggunakan Adler-32.” Vol 5, Edisi 7 2016, Yogyakarta

[2] Ditto Narapratama. "Perbandingan Performasi Algoritma Adler-32 dan CRC-32 pada LibraryZlib.” Institut Teknologi Bandung, 2006

[3] T. Sutoyo, S.Si., M.Kom., “Teori Pengolahan Citra Digital.”Yogyakarta ANDI, Semarang UDINUS. 2009

[4] Darma Putra "Pengolahan Citra Digital" Yogyakarta, ANDI, 2010

[5] Rifki Sadikin "Kriptografi untuk keamanan jaringan” Yogyakarta, ANDI, 2012 